\title{
Accumulation and clearance of tissue residues and health status of Nile tilapia Oreochromis niloticus (L.) juveniles as influenced by the extended oral oxytetracycline-dosing
}

Thangapalam Jawahar Abraham ( $\square$ abrahamtj1@gmail.com )

West Bengal University of Animal and Fishery Sciences https://orcid.org/0000-0003-0581-1307

Anwesha Roy

West Bengal University of Animal and Fishery Sciences

Roy Beryl Julinta

West Bengal University of Animal and Fishery Sciences

Jasmine Singha

West Bengal University of Animal and Fishery Sciences

Prasanna Kumar Patil

ICAR - Central Institute of Brackishwater Aquaculture

Edapparambil Krishnappan Nanitha Krishna

Central Institute of Fisheries Technology

Ravindran Rajisha

Central Institute of Fisheries Technology

Kesavan Ashok Kumar

Central Institute of Fisheries Technology

Research Article

Keywords: Oreochromis niloticus, Oxytetracycline, Oral dosing, OTC-residues, Histopathology, Fish health

Posted Date: March 1st, 2021

DOI: https://doi.org/10.21203/rs.3.rs-164142/v1

License: @ (i) This work is licensed under a Creative Commons Attribution 4.0 International License. Read Full License 


\section{Abstract}

Antibiotics are considered an important primary therapy for bacterial diseases in aquaculture. This study evaluated the influence of oral administration of oxytetracycline (OTC) on feed intake, growth, mortality, residue accumulation and clearance, and histopathological changes in the vital organs of six groups of Nile tilapia Oreochromis niloticus when fed at 0-10 times the therapeutic dose (1X: $80 \mathrm{mg} / \mathrm{kg}$ biomass/day) for 10 and 20 consecutive days. The feed intake was reduced only slightly, viz., $2 \%$ in 10 days and $4.25 \%$ in 20 days dosing trials at $1 \mathrm{X}$-dose compared to control. While in other groups, an OTCdose-dependent reduction in feed intake up to $31.25 \%$ was noted. The fish of $0.5 \mathrm{X}$ and $1 \mathrm{X}$ groups recorded significantly high biomass; while the other OTC-dosed groups recorded significantly lower biomass than the control. The fold change in biomass between the control and $1 \mathrm{X}$ groups was insignificant. A dosedependent mortalities were recorded in OTC-dosed fish in 10 days $(1.67 \pm 2.89-6.67 \pm 2.89 \%)$ and 20 days $(3.33 \pm 2.89-8.33 \pm 2.89 \%)$ trials. The OTC concentration in fish muscle established a dose- and timeresponse relationship. The OTC residue levels in muscle even on day 20 OTC-dosing were lower than the maximum residue limit permitted by Codex Alimentarius $(200 \mathrm{ng} / \mathrm{g})$. On day 23 post-OTC-dosing, the residue levels were traces to $<10 \mu \mathrm{g} / \mathrm{g}$ in all groups, except the 10X group. The OTC-dosing caused mild to moderate pathological changes in the gills, liver and kidney of 0 . niloticus and the fish were able to mount adaptive biological responses to overcome the stress with time.

\section{Introduction}

World food fish aquaculture production increased from 32.4 million tonnes in 2000 to 82.1 million tonnes in 2018 (FAO 2020). Tilapia (Oreochromis spp.) are the third most farmed and intensively cultured fish worldwide. Among the tilapia, production of Nile tilapia Oreochromis niloticus increased to 4.5254 million $\mathrm{mt}$, with a share of $8.3 \%$ of the total world aquaculture production in 2018 . The Chinese tilapia trade is the largest in the world (FAO 2020). The disease is one of the major predicaments that have an outcome on the tilapia production and livelihood of the farmers. Antibiotics are considered an important primary therapy for bacterial diseases in aquaculture (Hernandez 2005; Romero et al. 2012). Tetracyclines are widely used in the aquaculture industry because of their wide spectrum antibacterial activity (Wen et al. 2006; Romero et al. 2012). The United States Food and Drug Administration (USFDA) approved antibiotic oxytetracycline (OTC) is the most widely used chemotherapeutics to treat specific and systemic bacterial infections of finfish (USFWS 2015; Julinta et al. 2019a, b). Many reports are available on the application of OTC and its usefulness in controlling the bacterial diseases in aquaculture (Hernandez 2005; Watts et al. 2017; Limbu et al. 2020). However, the abuse of antibiotics in animal husbandry and aquaculture, as well as lack of awareness on the withdrawal time after treatment, have resulted in their release into the surrounding environments and emergence of antibiotic resistance in pathogenic bacteria (Watts et al. 2017; Limbu et al. 2020). Furthermore, the presence of antibiotic residues in food fish might cause adverse reactions in some susceptible consumers (Romero et al. 2012; Watts et al. 2017; Limbu et al. 2020). 
Across the world, the apprehension on the consumption of food fish treated with antibiotics has been increasing due to the impact on the economy, public health and consumers' ethics (Chen et al. 2020). However, the information on direct human health risk through consumption of antibiotics contaminated food fish are lacking (Limbu et al. 2018, 2020). To ensure the safety of food supply for consumers and simplify international trade, the maximum residue limit (MRL) for OTC residues in fish muscle has been established as $100 \mathrm{ng} / \mathrm{g}$ by European Union [EU] (Anonymous 2010a) and $200 \mathrm{ng} / \mathrm{g}$ by the Codex Alimentarius (Anonymous, 2006), Canada (Anonymous 2010b) and Japan (Anonymous 2011). Further, the safety data on the farmed fish are required as part of the drug registration process in most countries. In fish, the drug metabolism is generally temperature-dependent so also the toxicity, which is greater at higher temperatures (Li et al. 2012). Also, the potential effects of medicated feed administration in tropical fish are limited. The aquaculture use of antibiotics is reportedly caused numerous effects on the developmental, cardiovascular and metabolic systems of fish than their primary purpose, which may vary with species and life stage, antibiotics types, mode of action, dose and dosages (Yang et al. 2020). Besides, the antibiotics may affect growth performance of the cultured fish through enhanced oxidative stress, body damage, impaired nutrients metabolism, feed utilization efficiency and immunosuppression (Limbu et al. 2020). In global aquaculture, at least eight different groups of antibiotics, dominated by tetracyclines, are used. Among them, OTC is the most abused (Limbu et al. 2020). This study, therefore, evaluated the effects of oral administration of OTC at different concentrations on the feed intake, growth, mortality, residue accumulation and clearance and pathological damages in the tissues of vital organs of Oreochromis niloticus juveniles when fed for 10 and 20 consecutive days at $22-26^{\circ} \mathrm{C}\left(22.82 \pm 0.78^{\circ} \mathrm{C}\right)$.

\section{Materials And Methods}

\section{Experimental fish, design and set up for 10 and 20 days oxytetracycline-dosing trials}

The stocks of Nile tilapia Oreochromis niloticus juveniles of size $10.39 \pm 0.67 \mathrm{~cm}$ and $13.40 \pm 0.48 \mathrm{~g}$ were collected from a grow-out system, packed in oxygen-filled bags and transported to the laboratory. The fish were acclimatized for 15 days in circular fibreglass reinforced plastic (FRP) tanks of 500-L capacity. Polypropylene tanks of size L58 $\times \mathrm{H} 45 \times \mathrm{B} 45 \mathrm{~cm}$ were used for the feeding trials. Each tank was filled with 80-L bore-well water and conditioned for three days. Each tank was then stocked with 20 fish from the acclimatized stocks and protected by nylon net cover.

The safety of OTC in Nile tilapia was evaluated through oral administration for 10 days ( 10 days trial) and 20 days ( 20 days trial) separately. The therapeutic dose of OTC, as approved by the USFDA, is 2.50-3.75 $\mathrm{g} / 100$ pounds body weight/day (or $55-82.5 \mathrm{mg} / \mathrm{kg}$ biomass/day) for 10 consecutive days (USFWS 2015). The therapeutic dose of $80 \mathrm{mg} / \mathrm{kg}$ biomass/day was considered a $1 X$ dose in this study. For each trial, the fish were grouped into 6 groups namely control (0X), 0.5X, 1X, 3X, 5X and 10X groups, in triplicate. The fish were fed with $2 \%$ of the bodyweight (BW) for thrice daily. The faecal materials and other wastes were removed daily. About $50 \%$ of the water was exchanged once in 3 days.

\section{Oxytetracycline feeds preparation}


Five medicated feeds with varied OTC concentrations were prepared by adding required quantities of oxytetracycline dihydrate powder (HiMedia, India) as described in our earlier studies (Julinta et al. 2019a,b). In brief, the weighed OTC powder was mixed separately in $5 \mathrm{~mL}$ refined vegetable oil and then admixed with $1 \mathrm{~kg}$ basal pellet feed. The control feed was prepared as above without antibiotic. After proper mixing, the control and OTC-feeds were air-dried under the fan for a day and stored separately in airtight plastic containers at room temperature. The experimental protocols fulfilled the ethical guidelines including adherence to the legal requirements of India (CPCSEA 2018).

\section{Safety of oxytetracycline (OTC)-dosing}

The total experimental period was 40 days. The fish of all the treatment groups were given the appropriate OTC-feeds at $2 \%$ BW thrice daily to get a nominal therapeutic OTC-dose of $40 \mathrm{mg}(0.5 \mathrm{X}), 80 \mathrm{mg}(1 \mathrm{X}), 240$ $\mathrm{mg}(3 \mathrm{X}), 400 \mathrm{mg}(5 \mathrm{X}), 800 \mathrm{mg}(10 \mathrm{X}) / \mathrm{kg}$ biomass/day. The control group received the control feed (0X). The fish of 10 and 20 days of dosing trials were offered the control feed during the pre-dosing period (day 1-7). During the 10 days (day 8-17) and 20 days (day 18-27) dosing periods, the fish from groups $0.5 \mathrm{X}-10 \mathrm{X}$ were fed with appropriate OTC-feeds. After the completion of dosing, i.e., the post-OTC-dosing period (day 18-40 for 10 days trial) and (day 28-40 for 20 days trial), control feed was offered to all the groups. The daily observations include mortality, external signs of infections and behavioural changes. The observed behavioural changes were the position of fish in the water column, gasping for air, flashing, hyperactivity, lethargy, loss of equilibrium, pigmentation or discolouration and other unusual behaviour or signs. The biomass of at least 10 tilapia from each group was measured on day $0,10,20,30$ and 40 . The tank-wise uneaten feed pellets, if any, were collected after $90 \mathrm{~min}$ of each feeding, air-dried and weighed daily. The feeding behaviour of the experimental tilapia was noted daily and given qualitative (numerical) scores from 0-4, based on the amount of feed consumed (Bowker et al. 2015).

\section{Oxytetracycline residue analysis by LC-MS/MS}

One fish from each tank were collected on day 0, day 10 and/or 20 OTC-dosing and on the last day of the experiment (day 40) for OTC-residue analysis. The fish were put to death humanely using clove oil $(50 \mu \mathrm{L} / \mathrm{L})$, decapitated, dissected carefully, observed for gross lesions and clinical signs in the vital organs, degutted, washed thoroughly and stored at $-20^{\circ} \mathrm{C}$. The stored fish tissue samples were packed in dry ice at 1:3 ratio and transported to the Central Institute of Fisheries Technology (CIFT), Kochi, India for LC-MS/MS analysis. Immediately on reaching, the samples were kept in $-20^{\circ} \mathrm{C}$. Before the extraction of OTC, the fish samples were thawed and collected the edible muscle tissues with the skin. The OTC residues from $2 \mathrm{~g}$ fish homogenates were extracted, purified and analysed as described in Sharma et al. (2020). The AB Sciex 4000 QTRAP Mass spectrometry coupled with Exion HPLC system was used for the residue analysis. The method of validation was as per 2002/657/EC decision (European Commission 2002).

\section{Histopathology}

The kidney, liver and gill tissues were collected on day 0 and day 10 and/or 20 OTC-dosing for histopathology from the 1X-dosed fish collected for LC-MS/MS analysis. The samples were fixed in Bouin's 
fixative for $48 \mathrm{~h}$ and transferred to $70 \%$ ethyl alcohol overnight. Histopathological analysis was carried out as described in Roberts (2012).

\section{Physicochemical characteristics of water}

The mercury thermometer and digital pH meter (Waterproof HTestr 10, Oakton) were used to measure the water temperature and $\mathrm{pH}$, respectively. The levels of ammonia, dissolved oxygen, nitrate, nitrite and total hardness in the rearing water were determined by APHA/AWWA/WEF (2012) methods.

\section{Statistical analyses}

The data generated through triplicate experiments are presented as mean \pm standard deviation. The non-parametric Kruskal-Wallis test with pair-wise comparisons was followed to analyze the feeding behaviour data. The significance of differences in mortalities and biomass were analyzed by one-way ANOVA and Tukey HSD Posthoc for the comparison of means. Statistical Package for Social Sciences (IBM-SPSS) Version: 22.0 was used for the statistical analyses, considering a probability level of $\mathrm{P}<0.05$.

\section{Results}

The temperature of the rearing tank water was in the range of $21.00-26.00^{\circ} \mathrm{C}$. The minimum and the maximum values of dissolved oxygen were 4.20 and $4.90 \mathrm{mg} / \mathrm{L}$, respectively. The water $\mathrm{pH}$ levels were in the range of 7.80-8.60. The ammonia, nitrite and nitrate levels in the experimental tank water were in the range of $0.003-0.008 \mathrm{mg} / \mathrm{L}, 0.13-0.73 \mathrm{mg} / \mathrm{L}$ and $0.12-0.75 \mathrm{mg} / \mathrm{L}$, respectively. The hardness of the rearing water ranged from 710.00 to $798.00 \mathrm{mg} / \mathrm{L}$.

\section{Effect of 10 days oxytetracycline-dosing on feed intake, mortalities and biomass}

There was no change in the feeding behaviour of 0 . niloticus of $0.5 \mathrm{X}$ and control groups. The feed intake reduced with increasing OTC doses and the mean feeding behaviour scores decreased from $3.92 \pm 0.03$ in $1 \mathrm{X}$ to $2.75 \pm 0.13$ in $10 \mathrm{X}$. The feed intake reduced significantly among the treatment groups in a dosedependent manner as well as during the dosing period $(P<0.05)$. During the post-dosing period, a significant improvement in feed uptake was noted $(P<0.05)$, with scores in the range of $3.53 \pm 0.09$ in $10 \mathrm{X}$ $4.00 \pm 0.00$ in the $1 \mathrm{X}$ groups (Table 1). Mortalities were noted only in the higher OTC-dosed groups during the periods of OTC-dosing and within 3 days of post-OTC-dosing. On day 10 OTC-dosing, the observed mortalities were $3.33 \pm 2.89 \%$ and $6.67 \pm 2.89 \%$ in $5 \mathrm{X}$ and $10 \mathrm{X}$ groups. At the end of experimentation, mortalities in the range of $1.67-6.67 \%$ were noted in 3X-10X groups (Table 2). There existed significant differences in the mortalities of Nile tilapia between $0 \mathrm{X}$ and 10X during the dosing period, and between $0 \mathrm{X}$ and $5 \mathrm{X}$ as well as $10 \mathrm{X}$ during the post-dosing period $(\mathrm{P}<0.05)$. The biomass of OTC-dosed 0 . niloticus juveniles showed an increment pattern from day 0 . The fold increase in biomass differed significantly among the treatment groups $(P<0.05)$. The fold increase in the biomass of fish fed the $0.5 X$ and $1 X$ doses were significantly high compared to $0 X(2.32)$, with the highest at $0.5 X$, i.e., 2.51 times the initial weight. On the other hand, the fold increase in the biomass of fish fed the $3 \mathrm{X}-10 \mathrm{X}$ doses were significantly lower than 
the $0 \mathrm{X}(\mathrm{P}<0.05)$. The 5X and 10X-dosed fish recorded the least growth rate, i.e., 2.11 and 2.03 times the initial weight, respectively (Table 3 ).

\section{Effect of 20 days oxytetracycline-dosing on feed intake, mortalities and biomass}

Similar to the 10 days trial, reduced feed intake was noted in all cases compared to the pre-dosing period and/or control/0.5X groups. However, the reduction was more with the increase in OTC-dosing period to 20 days. The mean feeding behaviour scores ranged from $2.60 \pm 0.10(10 \mathrm{X})$ to $3.83 \pm 0.06(1 \mathrm{X})$. Significant differences existed in the feed intake among the treatment groups and dosing periods $(P<0.05)$. With the termination of OTC-dosing, the feed intake improved significantly in all the groups $(P<0.05)$ and the scores ranged from $3.31 \pm 0.09(10 \mathrm{X})$ to $4.00 \pm 0.00$ ( $1 \mathrm{X}$; Table 1 ). No mortalities were observed in control and $0.5 \mathrm{X}$ group until 40 days of observation. The mortalities were observed in $1 \mathrm{X}(1.67 \pm 2.89 \%)$ to $10 \mathrm{X}(8.33 \pm 2.89 \%)$ groups on day 20 OTC-dosing. In post-OTC-dosing period, mortalities in the range of $3.33 \pm 2.89$ in $1 \mathrm{X}$ $8.33 \pm 2.89 \%$ in $10 \mathrm{X}$ groups were noted (Table 2). Significant differences in the mortalities of Nile tilapia between the control and high OTC-dosed groups during the dosing (5X-10X) and post-dosing (3X-10X) periods were noted $(P<0.05)$. Also, the differences in the mortalities between the 10 and 20 days dosing trials of all OTC-dosed groups ( $1 X-10 X)$ were insignificant $(P>0.05)$. The fish of $0.5 X$ group recorded a significantly high fold change in biomass ( 2.45 times the initial weight) than the control $(P<0.05)$. The fold change in biomass between the $0 X(2.32)$ and $1 X(2.31)$ group was insignificant $(P>0.05)$. The fold changes in biomass in $3 X, 5 X$ and $10 X$ were $2.10,2.03$ and 1.99 times the initial weight, respectively, which were significantly lower $(P<0.05)$ than the control (Table 3$)$. The biomass of $0.5 \mathrm{X}$ group, though low in 20 days trial compared to the 10 days trial, the difference was insignificant $(P>0.05)$. The differences in the fold change in biomass of $1 X-10 X$ groups of 10 and 20 days trials were significantly different $(P<0.05)$.

\section{Abnormalities in oxytetracycline-dosed fish}

The abnormalities increased with the increase in OTC-dose and dosing period. The skin of OTC-dosed fish was normal except the $5 \mathrm{X}$ and $10 \mathrm{X}$ groups on day 20 , and 10X on day 30 , which had black patches on the skin. The gills of OTC-dosed fish appeared normal except for the 10X group on day 10- and 20-dosing, which exhibited reddening and excess mucus secretion. The intestines of $5 \mathrm{X}$ group were discoloured on day 10 and 20, while those of the $10 \mathrm{X}$ group were discoloured as well as swelled on day 10 to 20 . The swelling subsided on day 20 in 10 days trial and on day 30 in 20 days trial, but the discolouration of intestine persisted. On and after day 30 , all fish became normal and no abnormalities were observed. During the dosing period, the $3 \mathrm{X}, 5 \mathrm{X}$ and 10X OTC-dosed fish were gasping for air. All fish were distributed throughout the water column and there was no flashing, hyperactivity, lethargy and loss of equilibrium. The freshly dead fish were also subjected to necropsy, which had pale kidney and liver, discolouration and liquefaction of internal organs at the higher OTC doses.

\section{Oxytetracycline residues accumulation and clearance}

The residues in OTC-dosed 0 . niloticus juveniles for 10 and 20 days were analyzed by LC-MS/MS. No OTC-residues were found in control $O$. niloticus tissues as well as during the pre-dosing period. The residue levels increased in a dose-dependent manner from $63.71 \pm 3.82 \mu \mathrm{g} / \mathrm{g}$ in $0.5 \mathrm{X}$ to $397.15 \pm 12.33 \mu \mathrm{g} / \mathrm{g}$ 
in 10X groups on day 10 OTC-dosing. In 20 days OTC-dosing trial, the levels of tissue residues increased from $94.52 \pm 4.12 \mu \mathrm{g} / \mathrm{g}$ in $0.5 \mathrm{X}$ to $754.26 \pm 18.44 \mu \mathrm{g} / \mathrm{g}$ in $10 \mathrm{X}$ groups, respectively (Table 3 ). There existed significant differences in OTC-residue levels among the dosing groups and period $(P<0.05)$. On the last day of the experiment, the recorded residue levels were traces to $<10 \mu \mathrm{g} / \mathrm{g}$ in all groups, except for the $10 \mathrm{X}$ group. The residue levels were $12.78 \pm 1.61 \mu \mathrm{g} / \mathrm{g}$ and $85.20 \pm 3.69 \mu \mathrm{g} / \mathrm{g}$ for 10 and 20 days trials, respectively on day 23- and 13 post-OTC-dosing (Table 3 ).

\section{Histopathology}

The healthy O. niloticus juveniles had the normal architecture of the kidney (Fig. 1a), liver (Fig. 2a) and gills (Fig. 3a). The kidney histopathological sections of the $1 \mathrm{X}$-dosed $O$. niloticus juveniles exhibited disintegrated renal tubule, degenerated renal tubular epithelium and vacuolation on day 10 OTC-dosing (Fig. 1b). The 20-day OTC-dosed fish had disintegrated renal tubule, degenerated renal tubular epithelium, vacuolation, disintegrated glomerulus, inflamed renal tubule, widened lumen, constricted renal tubule and necrotised renal tubule (Fig. 1c). The liver of 10 days OTC-dosed group had moderate glycogen-type vacuolization, degenerated hepatocytes and cytoplasmic vacuolization (Fig. 2b). The 20 days OTC-dosed fish exhibited extensive glycogen-type vacuolization, degenerated hepatocytes, cytoplasmic vacuolization and necrotised liver parenchyma (Fig 2c). The gill histopathological sections of the $1 \mathrm{X}$-dosed 0 . niloticus juveniles revealed lamellar fusion, curling of secondary lamellae and desquamation on day 10 OTC-dosing (Fig. 3b). The 20 days OTC-dosed group had lamellar congestion, lamellar fusion, desquamation, lamellar epithelial lifting, ruptured secondary lamellae, swelled lamellar tip and thinning of secondary lamellae (Fig. 3c).

\section{Discussion}

Intensification of aquaculture favoured the use of a wide range of chemicals including several classes of antibiotics (Hernandez 2005; Romero et al. 2012; Watts et al. 2017). The OTC is the most common one as it is an approved drug for aquaculture and has high potency against bacterial diseases (USFWS 2015). Drugs are assessed for the definition of their MRLs, and their environmental impact, safety and efficacy, which are relatively sparse in tropical aquatic species (Reimschuessel et al. 2005). Our results on Nile tilapia indicated that the feed intake was reduced only slightly, viz., $2 \%$ in 10 days trial and $4.25 \%$ in 20 days trial at the curative dose ( $80 \mathrm{mg} / \mathrm{kg}$ biomass/day) compared to control during the OTC-dosing period. On the other hand, a dose-dependent reduction in feed intake with the increase in OTC concentrations from $10 \%$ in $3 X$ to $31.25 \%$ in the $10 X$ group was noted. The reduced feed intake could be attributed to the action of OTC as a feeding deterrent, which can make feed less palatable (Toften and Jobling 1997; Limbu et al. 2020) and antibiotic mediated toxicity (Zhang et al. 2015). An enhanced feed intake was noted in 3X-10X doses with the termination of OTC, yet it was $2.00-11.75 \%$ lower than the normal score of 4.0 in 10 days trial. A similar trend was also noted in 20 days OTC-dosing trial, with a reduction of $17.00 \%$ in $3 X$ to $35.00 \%$ in the $10 X$ group. Though the feed intake increased upon the termination of OTC-dosing, it was lower by $4.25 \%$ in $3 X$ to $17.25 \%$ in the $10 \mathrm{X}$ group than the control. Likewise, a significant dose-dependent reduction in feed intake was noted in Nile tilapia when fed OTC 
(Julinta et al. 2019a; Limbu et al. 2020) or florfenicol (Gaikowski et al. 2013) for extended periods. On the other hand, Gaikowski et al. (2003) noted a slight reduction in feed consumption in Walleye (Sander vitreus) at the OTC-dose of $413 \mathrm{mg} / \mathrm{kg}$ body weight/day, equivalent to the $5 X$-dose of our study. Conversely, no dose-related effect on general fish behaviour or feeding behaviour was observed in juvenile sunshine bass when fed florfenicol-medicated feeds at $0,15,45$, and $75 \mathrm{mg} \mathrm{FFC} / \mathrm{kg} \mathrm{BW} /$ day for 20 days (Straus et al. 2012). Our results indicated that the feed intake may reduce by $>2$ folds if the dosing period is increased from 10 to 20 days or 5 folds if the therapeutic dose is increased by 3 times in healthy Nile tilapia. It is a cause for concern when treating the diseased fish.

Mortalities were observed only from the $3 X(1.67 \pm 2.89 \%)$ to $10 X(6.67 \pm 2.89 \%)$ groups in 10 days OTCdosing trial. On the other hand, dose-dependent high mortalities from $3.33 \pm 2.89 \%$ in $1 \mathrm{X}$ to $8.33 \pm 2.89 \%$ in 10X were recorded in 20 days OTC-dosed Nile tilapia. Our results agree with Trushenski et al. (2018), who recorded $3 \%$ mortality in Nile tilapia fed with $80 \mathrm{mg}$ OTC/kg biomass/day for 10 days. Julinta et al. (2019a) also recorded increased mortalities with the increase in OTC-dose, i.e., from $5.00 \pm 0.00 \%$ in $1 \mathrm{X}$ to $13.33 \pm 2.89 \%$ in $10 \mathrm{X}$ groups, respectively when fed for 30 consecutive days. The observations like pale kidney and liver, discolouration and liquefaction of internal organs at the higher doses (3X-10X groups) possibly indicated the consequence of toxicity upon long-term oral OTC-dosing that might have triggered the mortality. It has been opined that any antibiotic/drug dose higher than the permissible limit may result in toxicity reaction (Yang et al. 2020) or affect the parasympathetic nervous system (Limbu et al. 2020). The water quality parameters, except hardness, were optimally well within the acceptable ranges required for the normal growth of fish (Boyd 1979), which rule out as stressful factors for the observed mortalities.

In both 10 and 20 days trials, the $0.5 X$-dosed Nile tilapia recorded the highest growth rate, 2.45-2.51 times the initial weight, followed by 2.31-2.45 times in the $1 \mathrm{X}$ group. The lowest growth rate was recorded in $10 \mathrm{X}$ (1.99-2.03 times) followed by 5X (2.03-2.11 times) groups. The significant dose-dependent differences in the fold increase in the biomass of Nile tilapia among the dosing groups indicated that OTC at the higher doses may affect the growth so also in an earlier study with similar doses for 30 days dosing (Julinta et al. 2019a). The 0.5X-dose had significantly high growth increment, while the therapeutic dose (1X) did not affect the growth of Nile tilapia. It has been proved in many earlier studies (Sanchez-Martinez et al. 2008; Reda et al. 2013) that OTC at lower doses favoured the growth of fish including tilapia, possibly due to the reduction of the gastrointestinal tract bacteria and their consequences (Dibner and Richards 2005). Contrarily, many earlier studies have shown the negative effects of antibiotics on the feed digestibility (Toften and Jobling 1997), feed palatability and growth (Trushenski et al. 2018; Julinta et al. 2019a, b; Limbu et al. 2020), immune system (Guardiola et al. 2012), serum biomarkers (Julinta et al., 2019b) and various other functions of fish (Limbu et al. 2020; Yang et al. 2020). The abnormal changes observed on OTC-dosed Nile tilapia at the higher doses also elucidated the side effects of long-term use of antibiotics, similar to several earlier studies that suggested OTC can induce nephrotoxicity and hepatotoxicity (Nunes et al. 2015; Julinta et al. 2019b; Limbu et al. 2020; Yang et al. 2020).

Residual periods of different antibiotics in various fish species are not well studied and, thus, have scarce information. Oxytetracycline remains one of the most common antibiotic residues found in animal tissues (Granados-Chinchilla and Rodríguez 2017). It is an easily degradable drug but can stay in muscle as 
metabolites forms or the pond sediment for a certain period (Romero et al. 2012; Watts et al. 2017). The absorption and elimination period is greatly influenced by temperature (Li et al. 2012). The present study at $22-26^{\circ} \mathrm{C}$ recorded a dose-dependent OTC-residue increase during the dosing period both in 10 and 20 days trials. Nevertheless, the residue levels were well within the MRL prescribed by Codex Alimentarius (200 $\mathrm{ng} / \mathrm{g}$; Anonymous 2006) or slightly above the EU regulations (100 ng/g; Anonymous 2010a) on day 10 OTC-dosing $(119.75 \pm 6.72 \mathrm{ng} / \mathrm{g})$ at the therapeutic dose (1X group). The residue levels were traces to $<10$ $\mu \mathrm{g} / \mathrm{g}$ in all groups, except the $10 \mathrm{X}$ group, i.e., $12.78 \pm 1.61 \mu \mathrm{g} / \mathrm{g}$ and $85.20 \pm 3.69 \mu \mathrm{g} / \mathrm{g}$ for 10 and 20 days trials, respectively on the last day of the experiment. Likewise, many earlier studies noted residues of OTC in fish for several days or weeks (Reda et al. 2013; Elia et al. 2014; Limbu et al. 2020), which may pose an increased risk of the possible transfer of drug residues to the consumers (Mo et al. 2017; Limbu et al. 2020). Our results uphold the observations of Elia et al. (2014), who recorded significantly lower OTCresidue levels in carp muscle 10 days after the $75 \mathrm{mg} / \mathrm{kg}$ antibiotic withdrawal than the MRL permitted by the EU regulation. Our residue clearance data may be useful to the policymakers in establishing the best possible dosages or the withdrawal periods in cultured Nile tilapia.

The renal toxicity may affect the tubules or glomeruli directly or alter hemodynamics indirectly, inflammatory tissue injury, and/or obstruction of renal excretion (Seely et al. 2018). The disintegrated renal tubule, degenerated renal tubular epithelium and vacuolation were the major histological alterations observed in the kidney of 10 days OTC-dosed Nile tilapia. Besides these, the extended dosing caused more alterations like disintegrated glomerulus, inflammation of renal tubule, widened lumen, constricted renal tubule and necrosis of renal tubule. The onset of necrosis and other inflammatory changes in the renal tubules may be the outcome of the toxic effect of long-term oral OTC-dosing and oxidative stress (Limbu et al. 2020). Nevertheless, the changes were observed to be only mild to moderate. The tubular epithelium degeneration noticed in the kidney indicated that the damage can be toxic, ischemic, inflammatory or obstructive. It has been reported that the tetracycline interacts with organic anionic transporters (OATs) and mediates the renal excretion in the kidney, although tetracycline does not possess anionic moieties (Konig et al. 2013). These transport characteristics may lead to the accumulation of tetracycline and induction of tetracycline-associated nephrotoxicity (Yang et al. 2020). The lumen constriction in the collecting canals indicated low filtration rate. The observations on the vacuolation in the renal tubules can reflect an alteration of many cytoplasmic components (Seely et al. 2018). Similarly, cytoplasmic vacuolization in the kidney renal duct epithelium was demonstrated by Svobodova et al. (2006) in C. carpio when fed OTCfeed at a higher dose ( $15 \mathrm{~g} / \mathrm{kg}$ live weight). In contrast, the oral administration of low levels of OTC (150 $\mathrm{mg} \mathrm{OTC/kg} \mathrm{feed)} \mathrm{caused} \mathrm{no} \mathrm{alteration} \mathrm{of} \mathrm{the} \mathrm{kidney} \mathrm{tissues} \mathrm{of} \mathrm{Piaractus} \mathrm{mesopotamicus} \mathrm{(Carraschi} \mathrm{et} \mathrm{al.}$ 2012). The present study also noted inflammation in the renal tubules of OTC-dosed Nile tilapia upon extended dosing, possibly due to the presence of inflammatory cells within the tubule lumen, epithelium, or both. The inflammation of renal tubules (nephritis) and disintegrated glomerulus revealed a defective glomerular filtration of blood. The inflammation and loss of structural integrity of the renal tubules in OTCdosed fish may decrease the availability of ATP and impair the energy supply (Baldissera et al. 2017). A perusal of literature on the histopathological changes in the kidney of fish treated with various antibiotics at varied concentrations through different routes of administration indicated conflicting results. For example, several earlier studies reported no changes in the kidney of fish (Fairgrieve et al. 2005; Straus et 
al. 2012; Shiogiri et al. 2016); while others demonstrated histopathological alterations in the kidney (Reimschuessel and Ferguson 2006; Gaikowski et al. 2013). Our observation on the progressive increase in the renal changes with the duration of treatment validated earlier studies (Reimschuessel and Ferguson 2006; Gaikowski et al. 2013; Yang et al. 2020; Limbu et al. 2020).

The OTC-dosed Nile tilapia of the present study exhibited varying degrees of glycogen-type vacuolization in the liver. Glycogen vacuolization is a signal of the degenerative process, which can cause an increase in the size of hepatocytes or acute swelling of the organ (Rejeki et al. 2005). It may also result in depletion of the glycogen reserves in the hepatocytes (Wilhelm-Filho et al. 2001) and an imbalance in synthesis and release of metabolic substances (Senarat et al. 2015), thus, leading to stress in fish. The vacuolization of the hepatocytes was severe in 20 days OTC-dosed Nile tilapia than the 10 days dosed group, which suggested severe metabolic damage, possibly related to OTC-medication. It implied that vacuoles formation is a defence mechanism against OTC toxicity and may be an adaptive change to protect against liver injury (Wolf et al. 2015). The fish of both trials also had degeneration of hepatocytes and cytoplasmic vacuolization. Besides, the 20 days OTC-dosed group necrotised liver parenchyma, thus confirming the hepatotoxic effect of OTC. Alike, the histopathological sections of the gill of $1 X$-dosed $O$. niloticus revealed varying degrees of changes on the gills upon extended OTC-dosing. Changes observed on 10 days OTC-dosed fish were lamellar fusion, curling of secondary lamellae and desquamation. The 20 days OTC-dosed group had more severe pathological changes, viz., lamellar congestion, desquamation, lamellar epithelial lifting, ruptured secondary lamellae, swelled lamellar tip and thinning of secondary lamellae. Tissue damages in the gills, as reported here due to extended OTC-dosing, may reduce the oxygen up-take and disturb the osmoregulatory functions of the fish. Similarly, tetracyclines or OTC induced pathological changes in Oncorhynchus mykiss (Rodrigues et al. 2017) and Gambusia holbrooki (Nunes et al. 2015), possibly associated with circulatory disturbances and oxidative stress, have been demonstrated In contrast, zebrafish Danio rerio exposed to OTC at 10-50 mg/L levels failed to show changes in the gill tissues (Oliveira et al. 2013).

\section{Conclusion}

The effects of OTC on the reduced in feed intake and biomass and increased mortalities were observed to be dose-dependent. The OTC concentration in muscle demonstrated a dose- and time-response relationship. The OTC residue levels in muscle even on day 20 OTC-dosing at $80 \mathrm{mg} / \mathrm{kg}$ biomass/day were lower than the MRL permitted by Codex Alimentarius $(200 \mathrm{ng} / \mathrm{g})$. The data on the residue clearance can be useful in establishing the safe withdrawal period in cultured Nile tilapia. From the results of the present study, it can be concluded that oral OTC administration at $80 \mathrm{mg} / \mathrm{kg}$ biomass/day for 10 consecutive days at $22-26^{\circ} \mathrm{C}$ did not affect the survival, feed intake and growth performance. Though the oral OTC-dosing caused mild to moderate pathological changes in the gills, liver and kidney, the Nile tilapia were able to mount biological adaptive responses to overcome the stress with time.

\section{Declarations}


Acknowledgement The authors thank the Vice-Chancellor, West Bengal University of Animal and Fishery Sciences, Kolkata for providing necessary infrastructure facility to carry out the work.

Authors' contributions TJA and PKP designed the study, contributed to study materials and consumables. AR, JS and RBJ performed the wet laboratory experiments, histopathology and generated the data. EKNK and RR performed the LC-MS/MS analysis. KAK interpreted the LC-MS/MS data. TJA performed statistical analyses, interpreted the data and wrote the manuscript. All authors agreed with the results and conclusions.

Funding The research work was supported by the Indian Council of Agricultural Research, Government of India, New Delhi under the All India Network Project on Fish Health (Grant F. No. CIBA/AINP-FH/2015-16 dated 02.06.2015).

Data availability The datasets used and/or analyzed during the current study are available from the corresponding author on reasonable request.

\section{Compliance with ethical standards}

Competing interests The authors declare that they have no known competing financial interests or personal relationships that could have appeared to influence the work reported in this paper.

Ethics approval and consent to participate All the experimental protocols were as per the guidelines of the Government of India and approved by the University Ethical Committee and the Indian Council of Agricultural Research, Government of India, New Delhi (F. No. CIBA/AINP-FH/2015-16 dated 16.7.2015) under the All India Network Project on Fish Health.

Consent for publication Not applicable.

\section{References}

Anonymous (2006) Residues of veterinary drugs in foods. Joint FAO/WHO Food Standards Programme, 29th Session, Codex Alimentarius Commission, Geneva, Switzerland.

Anonymous (2010a) Commission Regulation (EU) No 37/2010 of 22 December 2009 on pharmacologically active substances and their classification regarding maximum residue limits in foodstuffs of animal origin. Off J Eur Union L15:1-72.

Anonymous (2010b) Administrative Maximum Residue Limits (AMRLs) and Maximum Residue Limits (MRLs) set by Canada. Drugs and Health Products, Canada. http://www.hc-sc.gc.ca/dhp-mps/vet/mrlImr/mrl-Imr_versus_new-nouveau-eng.php.

Anonymous (2011) Maximum Residue Limits (MRLs) list of agricultural chemicals in foods. The Japan Food Chemical Research Foundation. http://m5.ws001.squarestart. ne.jp/foundation/search.html. 
APHA/AWWA/WEF (2005) Standard Methods for the Examination of Water and Wastewater, Twelfth ed. American Public Health Association, American Water Works Association and Water Environment Federation, Washington, USA.

Baldissera MD, Souza CF, Júnior GB, Verdi CM, Moreira KLS, da Rocha MIUM, da Veiga ML, Santos RCV, Vizzotto BS, Baldisserotto B (2017) Aeromonas caviae alters the cytosolic and mitochondrial creatine kinase activities in experimentally infected silver catfish: Impairment on renal bioenergetics. Microb Pathog 110:439-443. https://doi.org/10.1016/j.micpath.2017.07.031

Bowker J, Burbank D, Bowman MP, Wandelear N (2015) Efficacy of AQUAFLOR® (50\% Florfenicol) to control mortality in Chinook salmon diagnosed with bacterial kidney disease (2014). USFWS, AADAP, DRIB No. 4:1-3.

Boyd CE (1979) Water Quality in Warm Water Fish Ponds. Alabama Agriculture Experiment Station, Auburn University, Alabama.

Carraschi SP, da Cruz C, Machado Neto JG, Ignácio NF, Barbuio R, Machado MR (2012) Histopathological biomarkers in pacu (Piaractus mesopotamicus) infected with Aeromonas hydrophila and treated with antibiotics. Ecotoxicol Environ Saf 83:115-120. https://doi.org/10.1016/j.ecoenv.2012.06.016

Chen J, Sun R, Pan C-G, Sun Y, Mai B-X, Li QX (2020) Antibiotics and food safety in aquaculture. J Agric Food Chem. 68, 43, 11908-11919. https://doi.org/10.1021/acs.jafc.0c03996

CPCSEA (2018) Compendium of CPCSEA 2018. Committee for the Purpose of Control and Supervision of Experiments on Animals. Animal Welfare Division. Ministry of Environment Forest and Climate Change, Government of India, New Delhi. 202p.

Dibner JJ, Richards JD (2005) Antibiotic growth promoters in agriculture: history and mode of action. Poult Sci 84:634-643. https://doi.org/10.1093/ps/84.4.634

Elia AC, Ciccotelli V, Pacini N, Dorr AJM, Gili M, Natali M, Gasco L, Prearo M, Abete MC (2014) Transferability of oxytetracycline (OTC) from feed to carp muscle and evaluation of the antibiotic effects on antioxidant systems in liver and kidney. Fish Physiol Biochem 40:1055-1068.

https://doi.org/10.1007/s10695-013-9905-4

European Commission (2002) Council Regulation (EEC) No 2002/657/EC. Commission decision of 12 August 2002 implementing Council Directive 96/23/EC concerning the performance of analytical methods and the interpretation of results. Off $\mathrm{J}$ Eur Comm Notified under document number $\mathrm{C}$.

Fairgrieve WT, Masada CL, McAuley WC, Peterson ME, Myers MS, Strom MS (2005) Accumulation and clearance of orally administered erythromycin and its derivative, azithromycin, in juvenile fall Chinook salmon Oncorhynchus tshawytscha. Dis Aquat Org 64:99-106. https://doi.org/10.3354/dao064099 
FAO (2020) The State of World Fisheries and Aquaculture 2020. Sustainability in Action. Rome. https://doi.org/10.4060/ca9229en

Gaikowski MP, Wolf JC, Schleis SM, Gingerich WH (2003) Safety of oxytetracycline (Terramycin TM-100F) administered in feed to hybrid striped bass, walleyes, and yellow perch. J Aquat Anim Health 15:274-286. https://doi.org/10.1577/H03-042.1

Gaikowski MP, Wolf JC, Schleis SM, Tuomari D, Endri SRG (2013) Safety of florfenicol administered in feed to tilapia (Oreochromis sp.). Toxicol Pathol 41:639-652. https://doi.org/10.1177/0192623312463986

Granados-Chinchilla F, Rodríguez C (2017) Tetracyclines in food and feeding stuffs: from regulation to analytical methods, bacterial resistance, and environmental and health implications. J Anal Methods Chem 2017:1-24. https://doi.org/10.1155/2017/1315497

Guardiola FA, Cerezuela R, Meseguer J, Esteban MA (2012) Modulation of the immune parameters and expression of genes of gilthead seabream (Sparus aurata L.) by dietary administration of oxytetracycline. Aquaculture 334-337, 51-57. https://doi.org/10.1016/ j.aquaculture.2012.01.003

Hernández SP (2005) Responsible Use of Antimicrobials in Aquaculture. FAO Fisheries Technical Paper no 469, FAO, Rome, 97pp.

Julinta RB, Abraham TJ, Roy A, Singha J, Dash G, Mali P, Nagesh TS, Sar TK, Patil PK, Kumar KA (2019a) Effect of oxytetracycline-dosing on the growth, safety and intestinal histology of Nile tilapia, Oreochromis niloticus (L.) juveniles. Int J Curr Microbiol Appl Sci 8:2708-2724. https://doi.org/10.20546/ijcmas. 2019.808.313

Julinta RB, Abraham TJ, Roy A, Singha J, Boda S, Patil PK (2019b) Dietary influences of oxytetracycline on the growth and serum biomarkers of Oreochromis niloticus (L.). Ecotoxicol Environ Saf 186:109752. https://doi.org/10.1016/j.ecoenv.2019.109752

Konig J, Muller F, Fromm MF (2013) Transporters and drug-drug interactions: important determinants of drug disposition and effects. Pharmacol Rev 65:944-966. https://doi.org/10.1124/pr.113.007518

Li Z, Zhang W, Lu X, Li J, He B, Jiang H, Wang S, Lu Z, Wang C, Cao J (2012) Reaction temperature alters chorzoxazone metabolism in carp (Cyprinus carpio) hepatic microsomes. Fish Physiol Biochem 38:12251231. https://doi.org/10.1007/s10695-012-9605-5

Limbu SM, Zhou L, Sun S-X, Zhang M-L, Du Z-Y (2018) Chronic exposure to low environmental concentrations and legal aquaculture doses of antibiotics cause systemic adverse effects in Nile tilapia and provoke differential human health risk. Environ Int 115:205-219. doi: 10.1016/j.envint.2018.03.034

Limbu SM, Chen L-Q, Zhang M-L, Du Z-Y (2020) A global analysis on the systemic effects of antibiotics in cultured fish and their potential human health risk: a review. Rev Aquac 1-45 doi: 10.1111/raq.12511. 
Mo W, Chen Z, Leung H, Leung A (2017) Application of veterinary antibiotics in China's aquaculture industry and their potential human health risks. Environ Sci Pollut Res 24:8978-8989.

https://doi.org/10.1007/s11356-015-5607-z

Nunes B, Antunes SC, Gomes R, Campos JC, Braga MR, Ramos AS, Correia AT (2015) Acute effects of tetracycline exposure in the freshwater fish Gambusia holbrooki: antioxidant effects, neurotoxicity and histological alterations. Arch Environ Contam Toxicol 68:371-381. https://doi.org/10.1007/s00244-0140101-z

Oliveira R, McDonough S, Ladewig JCL, Soares AMVM, Nogueira AJA, Domingues I (2013) Effects of oxytetracycline and amoxicillin on development and biomarkers activities of zebrafish (Danio rerio). Environ Toxicol Pharmacol 36:903-912. https://doi.org/10.1016/j.etap.2013.07.019

Reda RM, Ibrahim RE, Ahmed EG, El-Bouhy ZM (2013) Effect of oxytetracycline and florfenicol as growth promoters on the health status of cultured Oreochromis niloticus. Egypt J Aquat Res 39:241-248. https://doi.org/10.1016/j.ejar.2013.12.001

Reimschuessel R, Ferguson HW (2006) Kidney. In: Ferguson HW (ed) Systemic Pathology of Fish: A Text and Atlas of Normal Tissues in Teleosts and their Responses in Disease, Scotian Press, London, pp. 91118.

Reimschuessel R, Stewart L, Squibb E, Hirokawa K, Brady T, Brooks D, Shaikh B, Hodsdon C (2005) Fish drug analysis-phish-pharm: A searchable database of pharmacokinetics data in fish. The AAPS J 7:E288327. https://doi.org/10.1208/aapsj070230

Rejeki S, Desrina D, Mulyana AR (2005) Chronic effects of detergent surfactant (Linear Alkylbenzene Sulfonate / LAS) on the growth and survival rate of sea bass (Lates calcalifer Bloch) larvae. J Coast Dev $8: 207-226$.

Roberts RJ (2012) Fish Pathology. John Wiley \& Sons, New Delhi.

Rodrigues S, Antunes SC, Nunes B, Correia AT (2017) Histological alterations in gills and liver of rainbow trout (Oncorhynchus mykiss) after exposure to the antibiotic oxytetracycline. Environ Toxicol Pharmacol 53:164-176. https://doi.org/10.1016/j.etap.2017.05.012

Romero J, Feijoó CG, Navarrete P (2012) Antibiotics in aquaculture - Use, abuse and alternatives. In: Carvalho E, David GS, Silva RJ (eds.) Health and Environment in Aquaculture. ISBN: 978-953-51-0497-1, InTech, pp. 159-199. https://www.intechopen. com/books/health-and-environment-inaquaculture/antibiotics-in-aquaculture-use-abuse-and-alternatives

Ruyck H, Ridder H (2007) Determination of tetracycline antibiotics in cow's milk by liquid chromatography/tandem mass spectrometry. Rapid Commun Mass Spectrom 21:1511-1520. https://doi.org/10.1002/rcm.2991 
Sanchez-Martinez JG, Perez-Castaneda R, Rabago-Castro JL, Aguire-Guzman G, Vazquez-Sauceda ML (2008) A preliminary study on the effects on growth, condition, and feeding indexes in channel catfish, Ictalurus punctatus, after the prophylactic use of potassium permanganate and oxytetracycline. J World Aquacult Soc 39:664-670. https://doi.org/10.1111/j.1749-7345.2008.00195.x

Seely JC, Hard GC, Blankenship B (2018) Kidney. In: Suttie A. (ed) Boorman's Pathology of the Rat, 2nd edn. Academic Press, USA, pp 125-166. https://doi.org/10.1016/B978-0-12-391448-4.00011-3

Senarat S, Kettratad J, Poolprasert P, Yenchum W, Jiraungkoorskul W (2015) Histopathological finding of liver and kidney tissues of the yellow mystus, Hemibagrus filamentus (Fang and Chaux, 1949), from the Tapee River, Thailand. Songklanakarin J Sci Technol 37:1-5. https://rdo.psu.ac.th/sjstweb/journal/371/37-1-1.pdf

Shiogiri NS, Ikefuti CV, Carraschi SP, da Cruz C, Fernandes MN (2016) Effects of azithromycin on tilapia (Oreochromis niloticus): Health status evaluation using biochemical, physiological and morphological biomarkers. Aquac Res 48:1-15. https://doi.org/10.1111/are.13191

Straus DL, Bowker JD, Bowman MP, Carty D, Mitchell AJ., Farmer BD (2012) Safety of aquaflor-medicated feed to sunshine bass. N Am J Aquacult 74:1-7. https://doi.org/10.1080/15222055.2011.630262

Svobodova Z, Sudova E, Nepejchalova L, Červinka S, Vykusova B, Modra H, Kolářová J (2006) Effects of oxytetracycline containing feed on pond ecosystem and health of carp (Cyprinus carpio L.). Acta Vet Brno 75:571-577. https://doi.org/10.2754/avb200675040571

Toften H, Jobling M (1997) Feed intake and growth of Atlantic salmon, Salmo salar L., fed diets supplemented with oxytetracycline and squid extract. Aquac Nutr 3:145-151.

https://doi.org/10.1046/j.1365-2095.1997.00081.x

Trushenski JT, Aardsma MP, Barry KJ, Bowker JD, Jackson CJ, Jakaitis M, McClure RL, Rombenso AN (2018) Oxytetracycline does not cause growth promotion in finfish. J Anim Sci 96:1667-1677. https://doi.org/10.1093/jas/sky120

USFWS (2015) Approved Drugs for Use in Aquaculture, second ed. U.S. Fish and Wildlife Service's Aquatic Animal Drug Approval Partnership Program, American Fisheries Society's Fish Culture and Fish Health Sections, Association of Fish and Wildlife Agencies, and Fisheries and Water Resources Policy Committee's Drug Approval Working Group.

Watts JE, Schreier HJ, Lanska L, Hale MS (2017) The rising tide of antimicrobial resistance in aquaculture: sources, sinks and solutions. Mar Drugs 15:158. https://doi.org/10.3390/md15060158

Wen Y, Wang Y, Feng YQ (2006) Simultaneous residue monitoring of four tetracycline antibiotics in fish muscle by in-tube solid-phase microextraction coupled with high-performance liquid chromatography. Talanta 70:153-159. https://doi.org/10.1016/j.talanta.2005.11.049 
Wilhelm Filho D, Torres MA, Tribess TB, Pedrosa RC, Soares CHL (2001) Influence of season and pollution on the antioxidant defenses of the cichlid fish acará (Geophagus brasiliensis). Braz J Med Biol Res 34:719-726. http://doi.org/10.1590/ S0100-879X2001000600004

Wolf JC, Baumgartner WA, Blazer VS, Camus AC, Engelhardt JA, Fournie JW, Frasca SJr, Groman DB, Kent ML, Khoo LH, Law JM, Lombardini ED, Ruehl-Fehlert C, Segner HE, Smith SA, Spitsbergen JM, Weber K, Wolfe MJ (2015) Nonlesions, misdiagnoses, missed diagnoses, and other interpretive challenges in fish histopathology studies a guide for investigators, authors, reviewers, and readers. Toxicol Pathol 43:297325. https://doi.org/10.1177/0192623314540229

Yang C, Song G, Lim W (2020) A review of the toxicity in fish exposed to antibiotics. Comp Biochem Physiol C- Toxicol Pharmacol 237:108840. https://doi.org/10.1016/j.cbpc.2020.108840.

Zhang Q, Cheng J, Xin Q (2015) Effects of tetracycline on developmental toxicity and molecular responses in zebrafish (Danio rerio) embryos. Ecotoxicology 24:707-719. doi: 10.1007/s10646-015-1417-9.

\section{Tables}

\section{Table 1}

Feeding behaviour numerical scores of oxytetracycline (OTC)-dosed Oreochromis niloticus at 0-10 times the therapeutic dose of $80 \mathrm{mg} / \mathrm{kg}$ biomass/day (X) for 10 and 20 consecutive days 


\begin{tabular}{|c|c|c|c|c|c|c|}
\hline \multirow[t]{2}{*}{ Period } & \multirow{2}{*}{$\begin{array}{l}\text { Dosing } \\
\text { days }\end{array}$} & \multicolumn{5}{|c|}{ Feeding behaviour scores: Range and mean \pm standard deviation } \\
\hline & & $\begin{array}{l}0 \mathrm{mg}(0 \mathrm{X}) \\
\text { and } \\
40 \mathrm{mg}(0.5 \mathrm{X})\end{array}$ & $\begin{array}{l}80 \mathrm{mg} \\
(1 \mathrm{X})\end{array}$ & $\begin{array}{l}240 \mathrm{mg} \\
(3 \mathrm{X})\end{array}$ & $\begin{array}{l}400 \mathrm{mg} \\
(5 \mathrm{X})\end{array}$ & $\begin{array}{l}800 \mathrm{mg} \\
(10 \mathrm{X})\end{array}$ \\
\hline $\begin{array}{l}\text { Pre- } \\
\text { dosing } \\
\text { period }\end{array}$ & $\begin{array}{l}10 \text { and } \\
20\end{array}$ & $\begin{array}{l}4.00 \\
(4.00 \pm 0.00)^{\mathrm{aA}}\end{array}$ & $\begin{array}{l}4.00 \\
(4.00 \pm 0.00) \\
\mathrm{aA}\end{array}$ & $\begin{array}{l}4.00 \\
(4.00 \pm 0.00) \\
\mathrm{aA}\end{array}$ & $\begin{array}{l}4.00 \\
(4.00 \pm 0.00) \\
\mathrm{aA}\end{array}$ & $\begin{array}{l}4.00 \\
(4.00 \pm 0.00) \\
\mathrm{aA}\end{array}$ \\
\hline \multirow[t]{2}{*}{$\begin{array}{l}\text { OTC- } \\
\text { dosing } \\
\text { period }\end{array}$} & $10^{*}$ & $\begin{array}{l}4.00 \\
(4.00 \pm 0.00) \\
\text { a } 1\end{array}$ & $\begin{array}{l}3.50-4.00 \\
(3.92 \pm 0.03)^{\mathrm{b} 2}\end{array}$ & $\begin{array}{l}3.00-4.00 \\
(3.60 \pm 0.05)^{\mathrm{b} 3}\end{array}$ & $\begin{array}{l}3.00-4.00 \\
(3.40 \pm 0.18) \\
b 4\end{array}$ & $\begin{array}{l}2.00-3.00 \\
(2.75 \pm 0.13) \\
\text { b5 }\end{array}$ \\
\hline & $20^{\star *}$ & $\begin{array}{l}4.00 \\
(4.00 \pm 0.00)^{\mathrm{A} 1}\end{array}$ & $\begin{array}{l}3.50-4.00 \\
(3.83 \pm 0.06)^{B 2}\end{array}$ & $\begin{array}{l}3.00-4.00 \\
(3.32 \pm 0.11)^{B 3}\end{array}$ & $\begin{array}{l}3.00-4.00 \\
(3.23 \pm 0.09)^{B 4}\end{array}$ & $\begin{array}{l}2.00-3.00 \\
(2.60 \pm 0.10)^{B 5}\end{array}$ \\
\hline \multirow[t]{2}{*}{$\begin{array}{l}\text { Post- } \\
\text { OTC- } \\
\text { dosing } \\
\text { period }\end{array}$} & $10^{*}$ & $\begin{array}{l}4.00 \\
(4.00 \pm 0.00) \\
\text { a } 1\end{array}$ & $\begin{array}{l}4.00 \\
(4.00 \pm 0.00) \\
\text { a } 1\end{array}$ & $\begin{array}{l}3.00-4.00 \\
(3.92 \pm 0.08) \\
\text { c2 }\end{array}$ & $\begin{array}{l}3.00-4.00 \\
(3.68 \pm 0.11) \\
c 3\end{array}$ & $\begin{array}{l}3.00-4.00 \\
(3.53 \pm 0.09)^{\mathrm{c} 4}\end{array}$ \\
\hline & $20^{\star *}$ & $\begin{array}{l}4.00 \\
(4.00 \pm 0.00)^{\mathrm{A} 1}\end{array}$ & $\begin{array}{l}4.00 \\
(4.00 \pm 0.00)^{\mathrm{A} 1}\end{array}$ & $\begin{array}{l}3.00-4.00 \\
(3.83 \pm 0.06)^{\mathrm{C} 2}\end{array}$ & $\begin{array}{l}3.00-4.00 \\
(3.46 \pm 0.09)^{\mathrm{C} 3}\end{array}$ & $\begin{array}{l}3.00-4.00 \\
(3.31 \pm 0.09)^{\mathrm{C} 4}\end{array}$ \\
\hline
\end{tabular}

*: 10 days OTC-dosing, i.e., 1-7 days: Pre-dosing period; 8-17 days: OTC-dosing period (OTC-dosing); 18-40 days: Post-0TC-dosing period; $* \star$ : 20 days OTC-dosing, i.e., 1-7 days: Pre-dosing period; 8-27 days: OTCdosing period (OTC-dosing); 28-40 days: Post-OTC-dosing period; 1-5: Values sharing uncommon numerical superscripts within a row for a particular dosing period differed significantly $(P<0.05)$. a-C; A-C: Values sharing uncommon alphabetical superscript within a column for a particular treatment (dose) differed significantly $(P<0.05)$.

\section{Table 2}

Mortalities in oxytetracycline (OTC)-dosed Oreochromis niloticus at 0-10 times the therapeutic dose of 80 $\mathrm{mg} / \mathrm{kg}$ biomass/day $(\mathrm{X})$ for 10 and 20 consecutive days 


\begin{tabular}{|c|c|c|c|c|}
\hline \multirow[t]{3}{*}{ Treatment groups } & \multicolumn{4}{|c|}{ Mortality (\%) } \\
\hline & \multicolumn{2}{|c|}{ OTC-dosing period } & \multicolumn{2}{|c|}{ Post-OTC-dosing period } \\
\hline & 10 days $^{\#}$ & 20 days $^{\$}$ & 10 days $^{\#}$ & 20 days $\$$ \\
\hline $0 \mathrm{mg}(\mathrm{OX})$ & $0.00 \pm 0.00$ & $0.00 \pm 0.00$ & $0.00 \pm 0.00$ & $0.00 \pm 0.00$ \\
\hline $40 \mathrm{mg}(0.5 \mathrm{X})$ & $0.00 \pm 0.00$ & $0.00 \pm 0.00$ & $0.00 \pm 0.00$ & $0.00 \pm 0.00$ \\
\hline $80 \mathrm{mg}(1 \mathrm{X})$ & $0.00 \pm 0.00$ & $1.67 \pm 2.89$ & $0.00 \pm 0.00$ & $3.33 \pm 2.89$ \\
\hline $240 \mathrm{mg}(3 \mathrm{X})$ & $0.00 \pm 0.00$ & $3.33 \pm 2.89$ & $1.67 \pm 2.89$ & $5.00 \pm 0.00^{\star}$ \\
\hline $400 \mathrm{mg}(5 \mathrm{X})$ & $3.33 \pm 2.89$ & $6.67 \pm 2.89^{*}$ & $5.00 \pm 0.00^{*}$ & $6.67 \pm 2.89^{*}$ \\
\hline 800 mg (10X) & $6.67 \pm 2.89^{*}$ & $8.33 \pm 2.89^{*}$ & $6.67 \pm 2.89^{*}$ & $8.33 \pm 2.89^{*}$ \\
\hline
\end{tabular}

\#: 10 days OTC-dosing, i.e., 1-7 days: Pre-dosing period; 8-17 days: OTC-dosing period (OTC-dosing); 18-40 days: Post-OTC-dosing period; \$: 20 days OTC-dosing, i.e., 1-7 days: Pre-dosing period; 8-27 days: OTCdosing period (OTC-dosing); $28-40$ days: Post-OTC-dosing period. Values with an asterisk ${ }^{*}$ ) within a column differed significantly from control $(P<0.05)$.

\section{Table 3}

Biomass and residues accumulation in oxytetracycline (OTC)-dosed Oreochromis niloticus at 0-10 times the therapeutic dose of $80 \mathrm{mg} / \mathrm{kg}$ biomass/day (X) for 10 and 20 consecutive days

\begin{tabular}{|lllll|}
\hline Treatment groups & \multicolumn{2}{l}{ Biomass: Fold increase in 40 days } & \multicolumn{2}{l|}{ OTC residues in the muscle $(\mathrm{ng} / \mathrm{g}) \#$} \\
\cline { 2 - 5 } & 10 days & 20 days & 10 days $^{\mathrm{a}}$ & 20 days $^{\mathrm{a}}$ \\
\hline $0 \mathrm{mg}(0 \mathrm{X})$ & $2.32 \pm 0.03^{1}$ & $2.32 \pm 0.02^{1}$ & $0.00 \pm 0.00^{1}$ & $0.00 \pm 0.00^{1}$ \\
\hline $40 \mathrm{mg}(0.5 \mathrm{X})$ & $2.51 \pm 0.04^{1 \mathrm{a}^{*}}$ & $2.45 \pm 0.04^{1^{*}}$ & $63.71 \pm 3.82^{1}$ & $94.52 \pm 4.12^{2}$ \\
\hline $80 \mathrm{mg}(1 \mathrm{X})$ & $2.45 \pm 0.05^{1 \mathrm{a}^{*}}$ & $2.31 \pm 0.02^{2}$ & $119.75 \pm 6.72^{1}$ & $183.13 \pm 11.97^{2}$ \\
\hline $240 \mathrm{mg}(3 \mathrm{X})$ & $2.15 \pm 0.02^{1 \mathrm{~b}^{*}}$ & $2.10 \pm 0.01^{2^{*}}$ & $163.52 \pm 3.54^{1}$ & $328.34 \pm 14.45^{2}$ \\
\hline $400 \mathrm{mg}(5 \mathrm{X})$ & $2.11 \pm 0.02^{1 \mathrm{~b} \mathrm{c}^{*}}$ & $2.03 \pm 0.02^{2 \mathrm{a}^{*}}$ & $218.65 \pm 8.43^{1}$ & $453.43 \pm 10.74^{2}$ \\
\hline $800 \mathrm{mg}(10 \mathrm{X})$ & $2.03 \pm 0.02^{1 \mathrm{c}^{*}}$ & $1.99 \pm 0.02^{2 \mathrm{a}^{*}}$ & $397.15 \pm 12.33^{1}$ & $754.26 \pm 18.44^{2}$ \\
\hline
\end{tabular}

Dosing periods are as in Table 2. \#: Data represent the observations made on day 10 or day 20 OTCdosing. The residue levels were traces to $<10 \mu \mathrm{g} / \mathrm{g}$ in all groups, except the $10 \mathrm{X}$ group, i.e., $12.78 \pm 1.61 \mu \mathrm{g} / \mathrm{g}$ and $85.20 \pm 3.69 \mu \mathrm{g} / \mathrm{g}$ for 10 and 20 days trials, respectively on the last day of the experiment. Values with 
an asterisk $\left(^{*}\right)$ within a column differed significantly from control $(P<0.05)$. a-c: Values sharing uncommon alphabetical superscripts within a column differed significantly $(P<0.05) .1,2$ : Values sharing uncommon numerical superscript within a row for a particular parameter differed significantly $(P<0.05)$. a: Values among the treatment groups within a column differed significantly $(P<0.05)$.

\section{Figures}

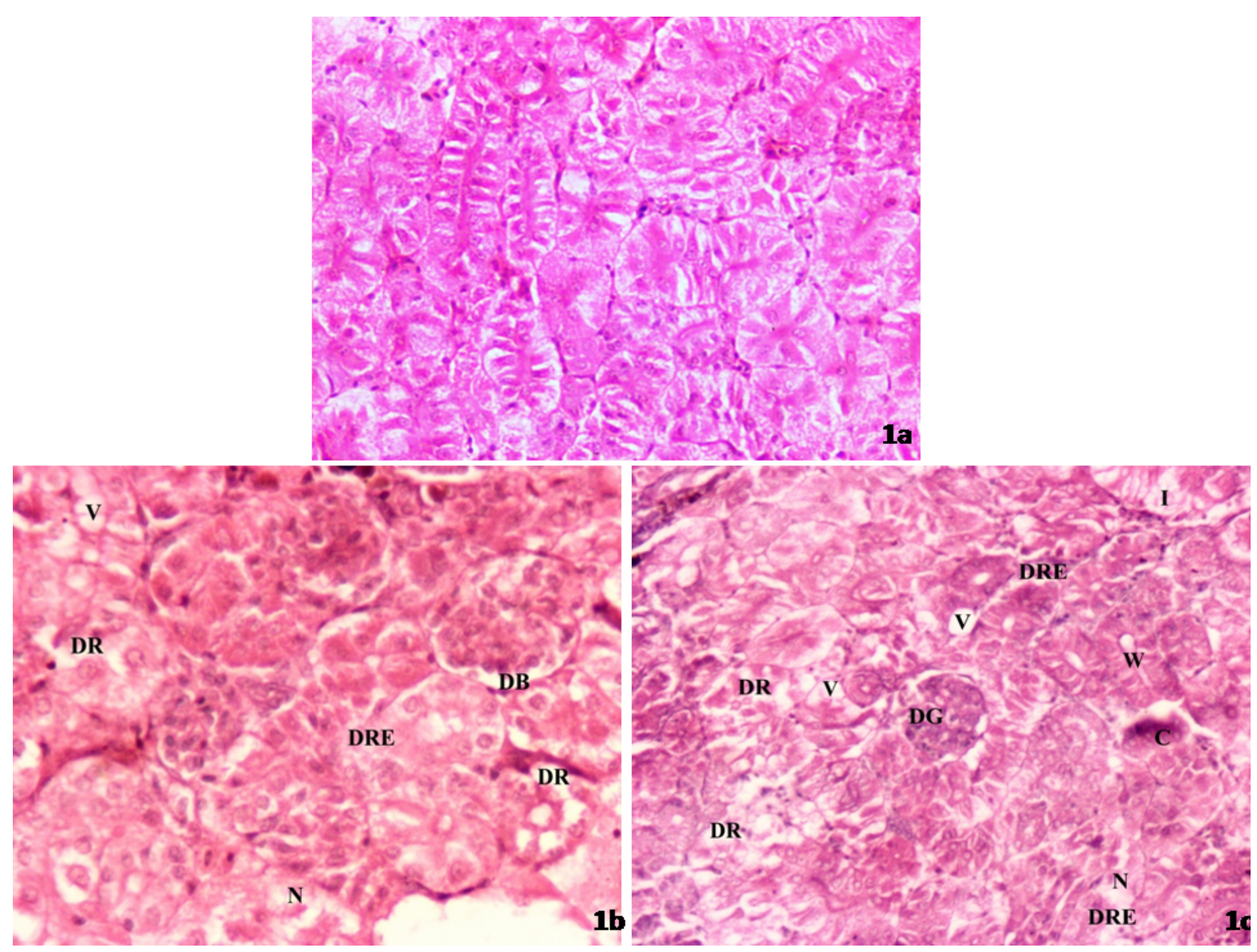

Figure 1

The histopathological sections of the [a] normal kidney of O. niloticus juveniles, X200 H\&E staining and [b] 1X-dosed fish showing disintegrated renal tubule (DR), degenerated renal tubular epithelium (DRE) and vacuolation (V) on day 10 OTC-dosing, X400 H\&E staining, and [c] disintegrated renal tubule (DR), degenerated renal tubular epithelium (DRE), vacuolation (V), disintegrated glomerulus (DG), inflammation of renal tubule (I), widened lumen $(\mathrm{W})$, constricted renal tubule $(\mathrm{C})$ and necrosis $(\mathrm{N})$ of renal tubule on day 20 OTC-dosing, X200 H\&E staining 


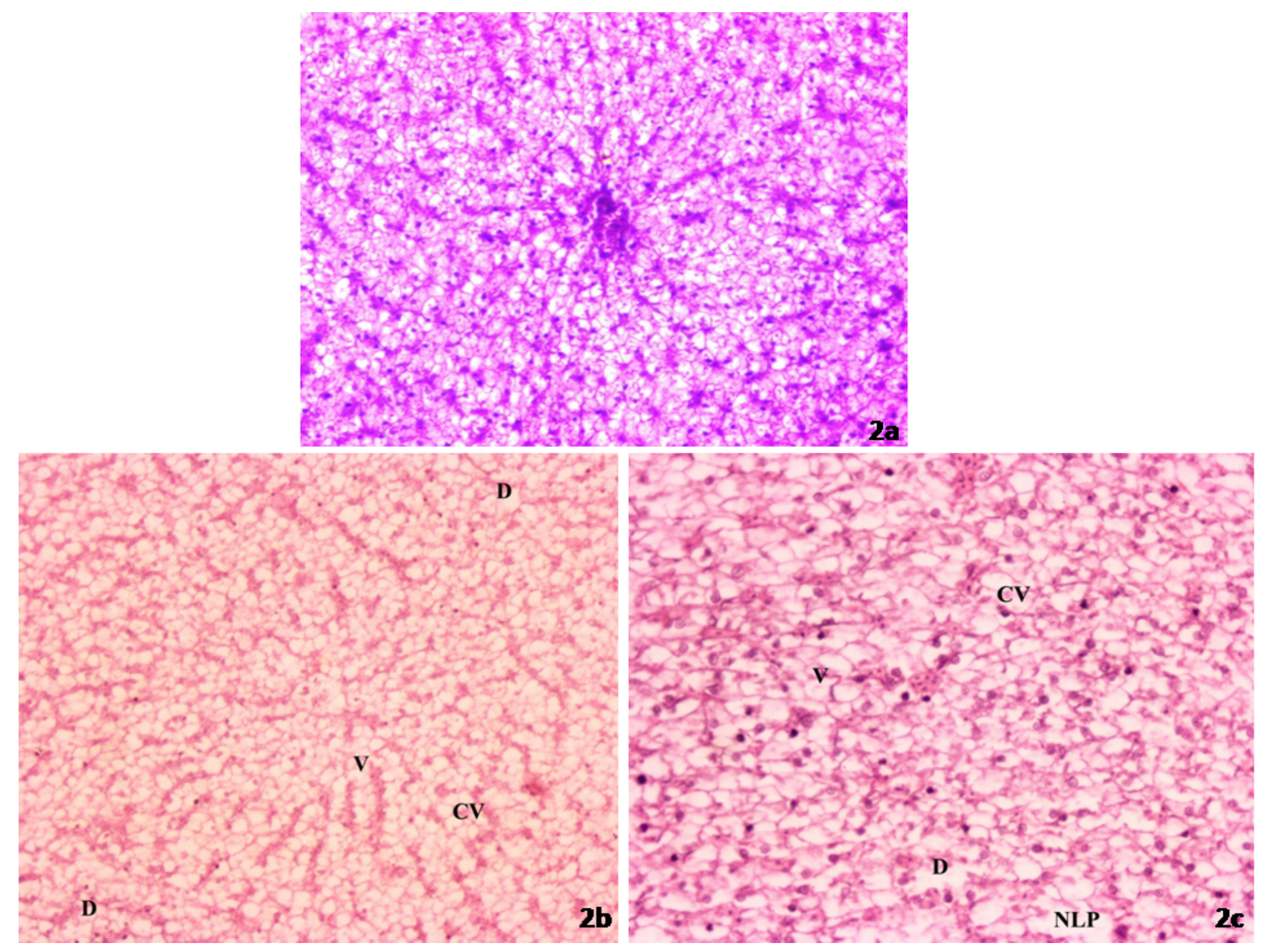

Figure 2

The histopathological sections of the [a] normal liver of O. niloticus juveniles, X200 H\&E staining and [b] 1X-dosed fish showing moderate glycogen-type vacuolization (V), degeneration of hepatocytes (D) and cytoplasmic vacuolization (CV) on day 10 OTC-dosing, X200 H\&E staining, and [c] extensive glycogen-type vacuolization (V), degeneration of hepatocytes (D), cytoplasmic vacuolization (CV) and necrotised liver parenchyma (NLP) on day 20 OTC-dosing, X200 H\&E staining 


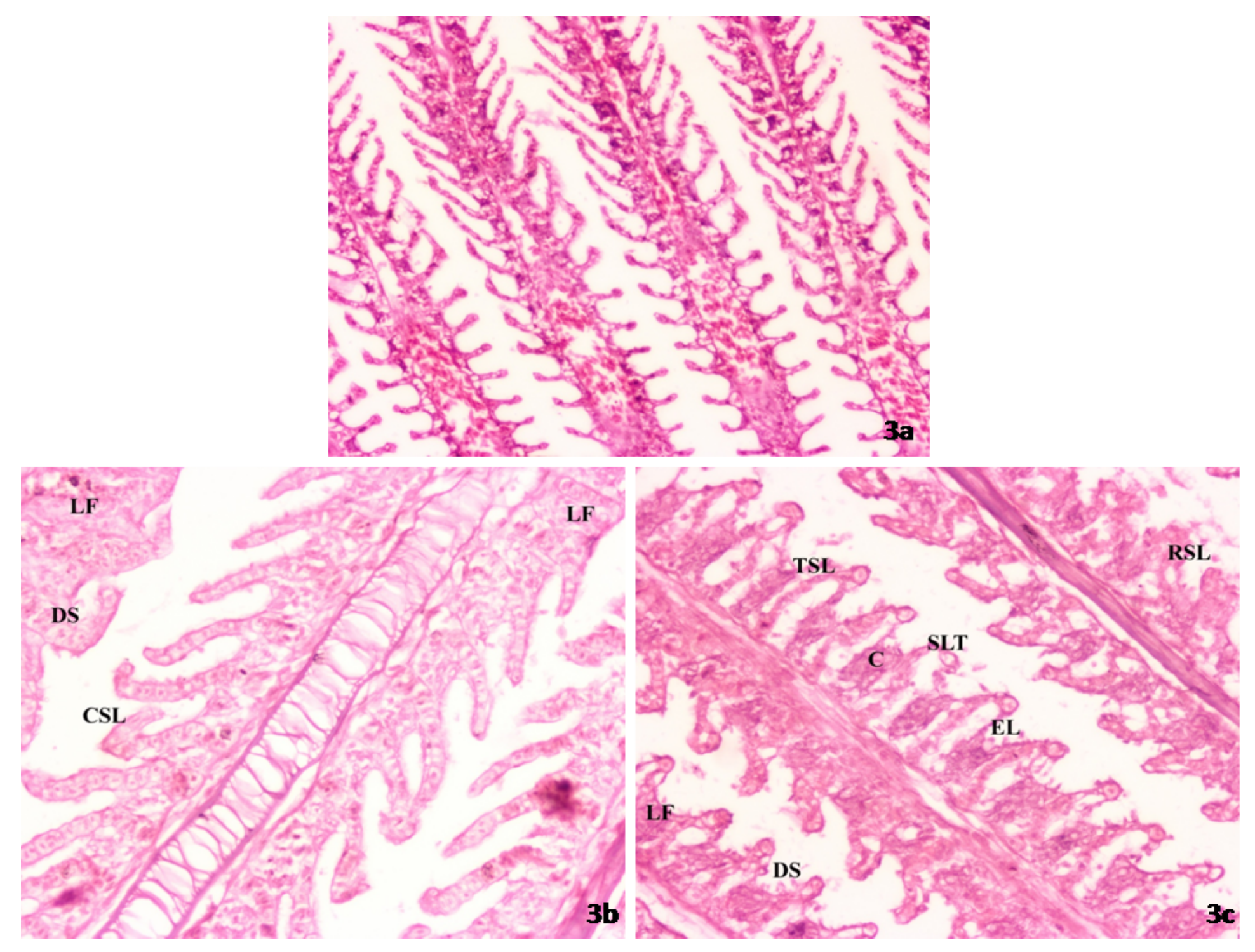

Figure 3

The histopathological sections of the [a] normal gill of O. niloticus juveniles, X100 H\&E staining and [b] 1Xdosed fish showing lamellar fusion (LF), curling of secondary lamellae (CSL) and desquamation (DS) on day 10 OTC-dosing, X200 H\&E staining and [c] lamellar congestion (C), lamellar fusion (LF), desquamation (DS), lamellar epithelial lifting (EL), ruptured secondary lamellae (RSL), swelled lamellar tip (SLT) and thinning of secondary lamellae (TSL) on day 20 OTC-dosing, X200 H\&E staining

\section{Supplementary Files}

This is a list of supplementary files associated with this preprint. Click to download.

- GraphicalanstractFinal.jpg 